Article

\title{
Leymann Inventory of Psychological Terror Scale: Development and Validation for Portuguese Accounting Professionals
}

\author{
Rui Silva ${ }^{1, *(1)}$, Margarida Simões ${ }^{2}$, Ana Paula Monteiro ${ }^{2}$ and António Dias ${ }^{1}$ \\ 1 Department of Economy, Sociology and Management, University of Trás-os-Montes e Alto Douro-CETRAD, \\ 5000-801 Vila Real, Portugal; acgdias@utad.pt \\ 2 Department of Education and Psychology, University of Trás-os-Montes e Alto Douro, \\ 5000-801 Vila Real, Portugal; margaridas@utad.pt (M.S.); apmonteiro@utad.pt (A.P.M.) \\ * Correspondence: rui.silva@utad.pt
}

check for

updates

Citation: Silva, Rui, Margarida Simões, Ana Paula Monteiro, and António Dias. 2021. Leymann Inventory of Psychological Terror Scale: Development and Validation for Portuguese Accounting Professionals. Economies 9: 94. https://doi.org/10.3390/ economies 9030094

Academic Editor:

Aleksander Panasiuk

Received: 8 March 2021

Accepted: 9 June 2021

Published: 23 June 2021

Publisher's Note: MDPI stays neutral with regard to jurisdictional claims in published maps and institutional affiliations.

Copyright: (c) 2021 by the authors. Licensee MDPI, Basel, Switzerland. This article is an open access article distributed under the terms and conditions of the Creative Commons Attribution (CC BY) license (https:// creativecommons.org/licenses/by/ $4.0 /)$.

\begin{abstract}
This research aims to adapt the Leymann Inventory of Psychological Terror and its use on Portuguese Accounting Professionals. Leymann scale was applied in a final sample of 478 accountants aged between 28 and 68 , of which $47.5 \%$ were men and $52.5 \%$ women. We used a quantitative methodology by applying a questionnaire survey whose results were, in the following research phase, analyzed using the statistical packages SPSS 26 and AMOS 27. We used SPSS 26 for the Descriptive Statistical Analysis and AMOS 27 to estimate the structural equation model that validated the scale. After the scale had been adapted and changed, it was validated in psychometric terms to be applied to and used in studies involving this type of professionals. The Accountants Leymann Inventory of Psychological Terror that resulted from adapting the original model was tested using structural equation modelling. Thus, the new scale produced significant results similar to those of the original scale, which means that it is valid and can be applied to other contexts. The validity and statistical reliability of the new scale made it possible to measure mobbing problems among accounting professionals reliably and robustly. The present research is an important contribution to the literature. Although it has been applied in several contexts, it is the first time it is being developed, adapted, and validated for accounting professionals who work in this area of management.
\end{abstract}

Keywords: mobbing; psychological terror; management; accounting professionals

\section{Introduction}

The main purpose of this research is to validate the Leymann Inventory of Psychological Terror (LIPT45) as regards Portuguese Accounting Professionals (PAP) who work in this area of management in Portugal. It focuses on a subject that has been little studied in Portugal: bullying or mobbing at work. Despite the scarcity of studies, in 2015, research based on a representative sample of 1801 working people was conducted, showing that bullying (48.1\%) and professional harassment $(46.5 \%)$ are the most common forms of bullying in the workplace in Portugal (Torres et al. 2016). Also, Portugal has only recently legislated on mobbing; it was first contemplated in article 24 of Law 99/2003 of 27 August of the Labour Code, which was later updated in October 2017, granting it a legal framework through Article 29 (Diário da República n.o 87/2017 2017).

The term mobbing was initially introduced in Sweden by Leymann (1990), and it means harassing or psychologically terrorizing other people in the workplace. Moral or psychological harassment starts with the abuse of power, resulting in the victim losing her/his self-esteem. What starts with a little lie or lack of respect can end up in violent manipulation on the part of the aggressor, reproducing these behaviors in all areas of the subject's life (workplace and family relationships) (de Freitas 2001; Monteiro et al. 2021).

Leymann (1990) was the first author to name the four phases of this phenomenon, going from the beginning of mobbing to the expulsion of the victim from the organization (Zapf and Gross 2001). In 1999, Hirigoyen (1999) conducted a study related to bullying 
at work and found that: in $58 \%$ of the cases, bullying is committed by the hierarchy, in $20 \%$ of the cases, by hierarchical superiors and colleagues, in $12 \%$ of the cases it originates from colleagues and only in $1 \%$ of the cases is it done by subordinates. In other words, the study allows us to understand how the different types of bullying at work are distributed (Hirigoyen 1999).

In other words, Hirigoyen's (1999) study allows us to understand how the different types of bullying at work are distributed. According to some authors, mobbing can be divided into three types: ascending (carried out by a subordinate or several, causing harm to the superior); horizontal (carried out among colleagues at the same hierarchical level, acting individually, or in groups); and vertical or bossing (practiced by the administrator, boss or superior who use power in an abusive way) (Leymann 1996; Luna et al. 2003; Thofehrn et al. 2008).

The literature points to evidence indicating that mobbing seriously affects the victims' health and well-being, the organizational performance, and even the social context (Bowling and Beehr 2006; Cooper et al. 2004; Figueiredo-Ferraz et al. 2015; Mikkelsen and Einarsen 2001).

Depending on the severity and prolongation of the situation, the consequences for the victim range from proven physical symptoms to mental and psychosomatic ones, such as stress, depression, low self-esteem, culpability phobias, sleep disorders, and digestive problems (Figueiredo-Ferraz et al. 2015; Mikkelsen and Einarsen 2001). The victims' families can also be socially and economically affected (Hershcovis et al. 2015).

Mobbing has been associated with increased costs for organizations due to reduced productivity, early retirement and employee absenteeism (Hauge et al. 2010; Leymann 1996), less work motivation, degradation of the company's image and decrease in customers (Duffy and Sperry 2007), and reduction in employees' innovative work behavior (Zhou et al. 2020).

There are organizational factors that can potentiate the occurrence of this phenomenon, namely, overload of work, fulfilment of objectives, organizational restructuring, excess of the workforce, reduction of jobs, competitive environments (Einarsen et al. 2011; Salin 2006; Thofehrn et al. 2008; Grau-Alberola et al. 2019), and difficult working conditions in which power relations prevail (Einarsen et al. 2011). In this sense, Rayner et al. (2003) suggest that in some organizations, mobbing is not integrated into the organizational culture. It is, nonetheless, indirectly consented since the lack of a policy against mobbing or punishment for those who practice it can be perceived as the organization allowing this type of behavior.

Accounting itself has been considered as an occupation with challenging and stress generating characteristics, namely a heavy workload, time pressure and conflicting duties, intolerance to errors, continuous changes in the regulations in force, and the need for a high level of concentration and deadlines to be met (Hasin and Omar 2007; Ozkan and Ozdevecioğlu 2013). Also, there are several sources of psychosocial stress in the accounting profession in Portugal, which may be related to the nature of their functions or to the institutional and economic context where it is performed (de Matos 2016). The same author also pointed out an overload of responsibilities inherent to the intrinsic characteristics of the activity itself, since the accounting generates a series of expectations in the entities that he/she collaborates, as he/she has to clarify the legal constraints, explain the consequences of the options to be taken and provide any relevant information that may affect him/her. Furthermore, the accounting professionals may also incur tax, criminal, misdemeanor, civil, labor, and disciplinary liability (de Matos 2016).

Thus, the quality of service and the efforts of accounting professionals may be more complex to evaluate compared to other professions, for example, the work of an employee in an assembly line. This aspect may represent a potential conflict-generating factor, such as permanently criticizing the colleague or the team leader (Zapf and Einarsen 2005; Monteiro et al. 2021). This situation can then increase micropolitical behavior and, therefore, the possibility of unresolved conflicts that can turn into mobbing (Zapf and Einarsen 2005).

Portuguese accountants are often faced with a heavy workload and great responsibility, besides having to fulfil urgent deadlines, facilitating the conditions for mobbing. This 
phenomenon is often a subjective process of social reconstruction, making it, therefore, difficult to prove, given that uninformed observers can interpret mobbing behaviors (for example, rudeness or indifference) in a completely different way, as the meaning of a specific behavior can be known only by the author and the addressee (Einarsen et al. 2011). Thus, instruments like the one presented in this article help detect mobbing actions in an organization or professional activity.

Ordinary people, who are not related to this area, may not understand the real meaning of mobbing behaviors (for example, rudeness or indifference) because victims and bullies only truly perceive the proper understanding of the effects of this behavior. Apart from these actors, only professionals can understand the true meaning and effects of this type of behavior on human beings.

Uninformed observers can interpret mobbing behaviors (for example, rudeness or indifference) in a completely different way, as the meaning of a specific behavior can be known only by the author and the addressee (Einarsen et al. 2011).

Given this problem, one must have rigorous instruments that help detect and understand this phenomenon in all its dimensions. In 1989, Leymann developed a questionnaire, referred to as the Leymann Inventory of Psychological Terrorization (LIPT), to assess the frequency of mobbing in an organization. The method was validated and managed to differentiate between "mobbed" and "non-mobbed employees".

Considering that the characteristics of the activity of accountants, mentioned above may enhance the occurrence of acts of mobbing, the present research aims to adapt the LIPT scale to Portuguese accountants by studying its psychometric properties.

\section{Literature Review}

\section{Leymann Inventory of Psychological Terror Scale}

LIPT is one of the most used instruments to assess mobbing. The LIPT questionnaire was developed in Sweden by H. Leymann and was validated in several countries, namely in France (Niedhammer et al. 2006). In the French version, adapted by Niedhammer et al. (2006), participants are also asked to consider whether they were subjected to hostile acts and witnessed mobbing directed to another employee during the previous 12 months. In this study, researchers explored the association between the characteristics of exposure to bullying in the workplace and depressive symptoms in a large sample of 3132 male and 4562 female employees in the southeast of France. Cases of bullying were defined using both Leymann's definition and self-reports of exposure to bullying. Depressive symptoms were measured using the Centre for Epidemiologic Studies Depression scale (CES-D). The main results were the following: (1) past exposure to bullying increased the risk of depressive symptoms; (2) observation of bullying became a risk factor for depressive symptoms, especially among women; (3) workplace bullying was a decisive risk factor for depressive symptoms for both men and women.

In Greece, Zachariadou et al. (2018) studied mobbing as a pervasive phenomenon with negative consequences for the victims' health and the organizations' productivity. A Greek version of the LIPT questionnaire was used after it had been translated from French. The questionnaire was distributed among 403 primary healthcare settings and of the largest public hospital in Cyprus. The response rate was $73.4 \%$.

Results showed that the most common forms of bullying were "being continuously interrupted" (17.2\%) and "being continuously given new work assignments" (13.5\%). Women were significantly more often exposed to at least one mobbing behavior than men within the previous year ( $49 \%$ vs. $35.7 \%$ ). In contrast, nurses were significantly exposed to at least one mobbing behavior compared to physicians (53.3\% vs. $31.4 \%$ ).

In Turkey, Korukcu et al. (2014) decided to adopt the Leymann Inventory of Psychological Terror (LIPT) to health sciences programs and to examine its psychometric qualities. A six-factor model was chosen to explain the modified LIPT scale based on the satisfactory fit indices from exploratory factor analyses. The factors indicated the relationship between different types of bullying acts. The most crucial conclusion showed that the modified 
LIPT scale is a reliable measurement tool that can be used with confidence, determining the reasons and types of bullying in health sciences programs.

Finally, Portuguese authors, Maximo et al. (2020a) looked into and adapted the inner structure of the Portuguese version of the Leymann Inventory of Psychological Terror (LIPT45), using a sample of 404 individuals (of which $70.5 \%$ were women) aged between 18 and 69 years of age. The LIPT45 revealed a coherent factorial structure and a more significant differentiation of its dimensions. Reliability indicators of both the dimensions and its scorings were adequate. Researchers concluded that the LIPT45 has psychometric features (such as inner structure and reliability) that render it a valuable tool to evaluate the dimension among adults. The instrument consists of 45 items assessing various types of mobbing behaviors; following Leymann's criteria (1990), a person is considered a victim of mobbing when exposed to at least one negative act per week for at least six months. There are five main dimensions, namely: (Self Expression Effects Effects); OSEQL (Occupational Situation Effects Quality of Life); SCE (Self Contacts Effects); SRE (Social Reputation Effects); and HE (Health Effects).

\section{Goal and Research Questions}

The present quantitative study proposes testing and validating LIPT45 dimensions using factor analysis, looking into the internal consistency of items and factors in what concerns accountants. In the present research, it can be translated into Portuguese and adapted explicitly to the accounting professionals. Validation of this scale applied to these areas of management will help build a new resource that can be used to measure this kind of mobbing in this particular field of knowledge, assessing its current state and giving indications as to what measures should be taken to improve it. Using data gathered from accountants who work in this area, the present study aims to adapt and validate the original LIPT45 by building an Accountants' Leymann Inventory of Psychological Terror (ALIPT) and testing the psychometric quality in terms of its reliability and statistic validity.

In order to fully attain the purposes of this research, it is vital to verify whether the forty-five items and five factors of LIPT45 have good reliability and validity when adapted to accountants of this management area; it is also essential to establish the factorial structure of the LIPT that is being adapted and applied to Portuguese Accounting Professionals by building an ALIPT and checking whether it has a satisfactory internal consistency. The LIPT, validated using Confirmatory Factor Analysis (CFA), has been translated, adapted, and applied in several countries, which shows the reliability and validity of the scale's psychometric properties.

\section{Methodology}

The study was conducted in three stages: (1) Utilization of LIPT45 Portuguese version and its adaptation to ALIPT; (2) Conduction of a pilot survey using modified ALIPT to assess the quality of the items that had been modified; (3) Application of ALIPT to Portuguese accountants. Details of each stage will be presented in the following sections.

After complying with the three stages described above, we followed the application of the quantitative methodology through the questionnaire survey, which was subsequently analyzed in two further stages: Descriptive Analysis using SPSS 26 software and the estimation of a structural model, using AMOS 27 software, capable of analyzing the robustness and reliability of the items of the measurement ladder. The adaptation of the scale was due to the need, on the one hand, to use a scale previously validated in another research context, and on the other hand, to adapt the items to the reality experienced by Portuguese accountants. The following sections explain in detail the adopted methodology.

\subsection{Adaptation of LIPT to ALIPT}

ALIPT was designed to evaluate the frequency of mobbing among accountants. A Portuguese version of the Leymann Inventory of Psychological Terror (LIPT45) (Maximo et al. 2020a). The LIPT45 is an instrument composed of 45 items with five response 
options: Nothing at all (0); A little (1); Moderately (2); Much (3); and Extremely (4). The items are divided into five dimensions: Self Expression Effects (e.g., "Your superiors do not let you express yourself or say what you have to say"); Occupational Situation Effects Quality of Life (e.g., "They force you to perform absurd or useless tasks"); Self Contacts Effects (e.g., "You cannot talk to anyone, everyone avoids them"); Social Reputation Effects (e.g., "They circulate false or unfounded rumors about you"); and Health Effects (e.g., "They make you do harmful or dangerous work").

As shown in Table 1, the LIPT45 scale has been used with accountants.

As we can see in Table 1, some scale items were modified to make them more understandable. The modification process was based on an analysis of the items by a Portuguese language teacher. The questionnaire was read by some professionals working in accounting offices, resulting in some modifications. The modified items were SEE7, SCE1, SCE2, SCE3, SCE5, SRE1, SRE7, and OSEQL1, essentially in the replacement of the term "People" by "Colleagues" in cases where the verb was in the first person and by "Accountants" in cases where it was important to mention the profession. We also replaced the word "Superior" by "Technical accounting manager "because this is the most correct designation for the CEO responsible for the accounting office in the accounting profession. In the profession's statutes, this is the official designation belonging to the profession's code of ethics.

All the changes were made by the researchers, with the support of three professionals from different areas: a Portuguese teacher helped with the grammatical terms, analyzing the whole scale and proposing some modifications; a psychologist analyzed the terms used from the point of view of mental health and issues related to the causes and effects of bullying in the workplace and an accountant, belonging to the Portuguese Accounting Professionals Association, analyzed the feasibility of the statements and technical terms used in the questions that were to be answered by colleagues working as accountants in Portugal.

\subsection{Pilot Study Using ALIPT}

The Leymann Inventory of Psychological Terror (LIPT45) was used in a series of questionnaires to determine whether the original intention behind LIPT45 items had been maintained and the accountants understood the statements that had been translated. This pilot study aimed to make sure the ALIPT did not need any adjustment, improvement or revision to make it more viable. This procedure is essential in assessing the validity of the modified instrument, granting it the required readability and consistency (Barbera and VandenPlas 2011).

In the pilot study, ALIPT was applied to 100 accountants, thus ensuring that it was valid and reliable. Before its application, the questionnaire was read aloud. Accountants were asked to speak out any doubts they might have in interpreting and rating it according to the Likert scale.

The statements were explained and doubts clarified; since the latter had only to do with some linguistic aspects, it was unnecessary to make any changes. Nevertheless, the questionnaire was followed by a brief conversation with the accountants to try and get to the bottom of their doubts. The feedback on that conversation showed doubts had only been momentary and immediately cleared away. 
Table 1. Original LIPT Scale.

\begin{tabular}{|c|c|c|c|}
\hline Dimensions & Variables & Original Scale (LIPT45)_ITEMS & Items Changed \\
\hline \multirow{11}{*}{$\begin{array}{l}\text { Self Expression } \\
\text { Effects }\end{array}$} & SEE1 & $\begin{array}{c}\text { Your superior restricts the opportunity for } \\
\text { you to express yourself }\end{array}$ & $\begin{array}{l}\text { Your technical accounting manager restricts } \\
\text { the opportunity for you to express yourself. }\end{array}$ \\
\hline & SEE2 & You are constantly interrupted. & You are constantly interrupted. \\
\hline & SEE3 & $\begin{array}{c}\text { Colleagues restrict your opportunity to } \\
\text { express yourself. }\end{array}$ & $\begin{array}{c}\text { Colleagues restrict your opportunity to } \\
\text { express yourself. }\end{array}$ \\
\hline & SEE4 & You are yelled at and loudly scolded. & You are yelled at and loudly scolded. \\
\hline & SEE5 & Your work is constantly criticized. & Your work is constantly criticized. \\
\hline & SEE6 & $\begin{array}{l}\text { There is constant criticism about your } \\
\text { personal life. }\end{array}$ & $\begin{array}{l}\text { There is constant criticism about your } \\
\text { personal life. }\end{array}$ \\
\hline & SEE7 & You are terrorized on the telephone. & $\begin{array}{l}\text { You are terrorized on the telephone by other } \\
\text { accounting officers. }\end{array}$ \\
\hline & SEE8 & Oral threats are made. & Oral threats are made. \\
\hline & SEE9 & Written threats are sent. & Written threats are sent. \\
\hline & SEE10 & Contact is denied through looks or gestures. & Contact is denied through looks or gestures. \\
\hline & SEE11 & Contact is denied through innuendo. & Contact is denied through innuendo. \\
\hline \multirow{5}{*}{$\begin{array}{l}\text { Self Contacts } \\
\text { Effects }\end{array}$} & SCE1 & People do not speak with you anymore. & Accountants do not speak with you anymore. \\
\hline & SCE2 & $\begin{array}{l}\text { You cannot talk to anyone; access to others } \\
\text { is denied. }\end{array}$ & $\begin{array}{l}\text { You cannot talk to anyone accountant; access } \\
\text { to others is denied. }\end{array}$ \\
\hline & SCE3 & $\begin{array}{l}\text { You are relocated to another room far away } \\
\text { from colleagues. }\end{array}$ & $\begin{array}{l}\text { You are relocated to another office far away } \\
\text { from colleagues. }\end{array}$ \\
\hline & SCE4 & Colleagues are forbidden to talk with you. & Colleagues are forbidden to talk with you. \\
\hline & SCE5 & You are treated as if you are invisible. & Colleagues are treated as if you are invisible. \\
\hline \multirow{15}{*}{$\begin{array}{l}\text { Social Reputation } \\
\text { Effects }\end{array}$} & SRE1 & $\begin{array}{l}\text { People talk badly about you behind } \\
\text { your back. }\end{array}$ & $\begin{array}{l}\text { Colleagues talk badly about you behind } \\
\text { your back. }\end{array}$ \\
\hline & SRE2 & $\begin{array}{l}\text { Unfounded rumours about you } \\
\text { are circulated. }\end{array}$ & $\begin{array}{l}\text { Unfounded rumours about you } \\
\text { are circulated. }\end{array}$ \\
\hline & SRE3 & You are ridiculed. & You are ridiculed. \\
\hline & SRE4 & You are treated as if you are mentally ill. & You are treated as if you are mentally ill. \\
\hline & SRE5 & $\begin{array}{l}\text { You are forced to undergo a } \\
\text { psychiatric evaluation. }\end{array}$ & $\begin{array}{l}\text { You are forced to undergo a } \\
\text { psychiatric evaluation. }\end{array}$ \\
\hline & SRE6 & Your handicap is ridiculed. & Your handicap is ridiculed. \\
\hline & SRE7 & $\begin{array}{l}\text { People imitate your gestures, walk, or voice } \\
\text { to ridicule you. }\end{array}$ & $\begin{array}{l}\text { Colleagues imitate your gestures, walk, or } \\
\text { voice to ridicule you. }\end{array}$ \\
\hline & SRE8 & $\begin{array}{l}\text { Your political or religious beliefs } \\
\text { are ridiculed. }\end{array}$ & $\begin{array}{l}\text { Your political or religious beliefs } \\
\text { are ridiculed. }\end{array}$ \\
\hline & SRE9 & Your private life is ridiculed. & Your private life is ridiculed. \\
\hline & SRE10 & Your nationality is ridiculed. & Your nationality is ridiculed. \\
\hline & SRE11 & $\begin{array}{l}\text { You are forced to do a job that affects your } \\
\text { self-esteem. }\end{array}$ & $\begin{array}{l}\text { You are forced to do a job that affects your } \\
\text { self-esteem. }\end{array}$ \\
\hline & SRE12 & $\begin{array}{l}\text { Your efforts are judged in a wrong and } \\
\text { demeaning way. }\end{array}$ & $\begin{array}{l}\text { Your efforts are judged in a wrong and } \\
\text { demeaning way. }\end{array}$ \\
\hline & SRE13 & Your decisions are always questioned. & Your decisions are always questioned. \\
\hline & SRE14 & You are called demeaning names. & You are called demeaning names. \\
\hline & SRE15 & Sexual innuendoes are present. & Sexual innuendoes are present. \\
\hline
\end{tabular}


Table 1. Cont

\begin{tabular}{|c|c|c|c|}
\hline Dimensions & Variables & Original Scale (LIPT45)_ITEMS & Items Changed \\
\hline \multirow{7}{*}{$\begin{array}{l}\text { Occupational } \\
\text { Situation } \\
\text { Effects and } \\
\text { Quality of Life }\end{array}$} & OSEQL1 & There are no special tasks for you. & $\begin{array}{l}\text { There are no special new accounting } \\
\text { tasks for you. }\end{array}$ \\
\hline & OSEQL2 & $\begin{array}{l}\text { Supervisors take away assignments so that } \\
\text { you cannot invent new tasks to do. }\end{array}$ & $\begin{array}{l}\text { Accounting technical manager take away } \\
\text { assignments so that you cannot invent new } \\
\text { tasks to do. }\end{array}$ \\
\hline & OSEQL3 & You are given meaningless jobs to carry out. & You are given meaningless jobs to carry out. \\
\hline & OSEQL4 & $\begin{array}{l}\text { You are given jobs that are below } \\
\text { your qualifications. }\end{array}$ & $\begin{array}{l}\text { You are given jobs that are below } \\
\text { your qualifications. }\end{array}$ \\
\hline & OSEQL5 & You are continually given new tasks. & You are continually given new tasks. \\
\hline & OSEQL6 & $\begin{array}{l}\text { You are given tasks that affect your } \\
\text { self-esteem. }\end{array}$ & $\begin{array}{l}\text { You are given tasks that affect your } \\
\text { self-esteem. }\end{array}$ \\
\hline & OSEQL7 & $\begin{array}{l}\text { You are given tasks that are way beyond } \\
\text { your qualifications in order to discredit you. }\end{array}$ & $\begin{array}{l}\text { You are given tasks that are way beyond } \\
\text { your qualifications in order to discredit you. }\end{array}$ \\
\hline \multirow{7}{*}{ Health Effects } & HE1 & $\begin{array}{l}\text { You are forced to do a physically } \\
\text { strenuous job. }\end{array}$ & $\begin{array}{l}\text { You are forced to do a physically } \\
\text { strenuous job. }\end{array}$ \\
\hline & HE2 & Threats of physical violence are made. & Threats of physical violence are made. \\
\hline & HE3 & Light violence is used to threaten you. & Light violence is used to threaten you. \\
\hline & HE4 & Physical abuse is present. & Physical abuse is present. \\
\hline & HE5 & $\begin{array}{l}\text { Causing general damages that create } \\
\text { financial costs to you. }\end{array}$ & $\begin{array}{l}\text { Causing general damages that create } \\
\text { financial costs to you. }\end{array}$ \\
\hline & HE6 & Damaging your workplace or home. & Damaging your workplace or home. \\
\hline & HE7 & Outright sexual harassment is present. & Outright sexual harassment is present. \\
\hline
\end{tabular}

\subsection{Participants}

ALIPT was applied through an online questionnaire to accountants who had volunteered to participate. The participants were recruited randomly, i.e., the questionnaire was sent to all Portuguese certified accountants by mail. This mailing was supported by the Ordem dos Contabilistas Certificados (OCC), the national organization that manages the rights and duties of its members-the accountants. These accountants come from various public and private organizations, working for different companies with different sizes and net profit volumes. It was not possible to know the organizations from which the respondents came or other financial information because the OCC did not allow it based on the ethical conduct guidelines they manage.

Respondents were accountants aged between 28 and 68 (with an average age of 45.16 years), of which $47.5 \%$ were men and $52.5 \%$ women. Of the 512 questionnaires gathered, 34 were excluded for not being filled in or containing more than one answer to one question. Overall, 478 valid questionnaires were obtained.

\subsection{Data Analysis}

In order to ascertain the available sample, a descriptive analysis of the data was done using IBM SPSS 23 software. The internal consistency and reliability of the LIPT45 items and factors (Pestana and Gageiro 2003) adapted for accounting professionals (resulting in the ALIPT) were also checked using the Cronbach's Alpha and its respective exploratory factor analysis (EFA).

EFA was used to simplify the set of data obtained, assessing how much each factor is associated with each variable and examining how all the factors account for the different results obtained in the sample through the sum of the variance of the original variables (Costello and Osborne 2005). After EFA had been done to determine the multifactor nature 
of the scale, and bearing in mind how items are spontaneously grouped, the Confirmatory Factor Analysis (CFA) was conducted using AMOS 27 software (Version 27.0, IBM, Armonk, NY, USA, 2021).

The CFA includes a set of techniques that measure the dimensions of a scale (Netemeyer et al. 2003) and allow one to test hypothesis regarding several factors, assessing the reliability of the indicators that represent the scale (Raykov and Marcoulides 2006). A minimum of five questionnaires per item is often recommended for factor analysis (Hair et al. 2010). According to the CFA, if an item has a high load, it indicates the factor and the item it corresponds to have much in common; loads under 0.32 are considered to be very weak, between 0.32 and 0.45 weak, between 0.45 and 0.63 good, and over 0.71 very good (Thompson 2004).

\section{Results}

\subsection{Exploratory Factor Analysis (EFA)}

In Portugal, studies on the LIPT45 structural model are scant; therefore, the original version of the LIPT scale was adopted, resulting in the ALIPT applied to accountants. In order to verify whether the factor model of ALIPT was in keeping with the literature, an Exploratory Factor Analysis was then conducted.

Factors and their respective oblique rotation were extracted using the Main Components Method (MCP), and only values whose factors were $\geq 1$ were considered. Results included a $\mathrm{KMO}=0.921$ and a five-factor correlation matrix that accounts for $61.86 \%$ of the variance. Factor 1 with a value of $41.62 \%$ explains most of the variance, followed by Factor 2 with 8. 41\%, Factor 3 with 4.53\%, Factor 4 with 3.87\%, and Factor 5 with 3.43\%.

Other extractions with a higher number of factors were simulated, maintaining the same extraction criterion: $\geq 1$. Factor distribution and variance percentage values were in keeping with other studies, in any case. This way, by using five factors, it was possible to verify that the exploratory factor model produced a structural model identical to the LIPT one. Table 2 presents the exploratory factor matrix regarding the 45 adapted items of ALIPT and their respective factor load, showing how variables are distributed into the five EFA ensuing factors.

Table 2. Exploratory Factor Analysis of the ALIPT sample regarding Portuguese students.

\begin{tabular}{|c|c|c|c|c|c|c|}
\hline \multicolumn{7}{|c|}{ Rotated Component Matrix } \\
\hline \multirow{2}{*}{ Dimensions } & \multirow{2}{*}{ Variables } & \multicolumn{5}{|c|}{ Factors } \\
\hline & & 1 & 2 & 3 & 4 & 5 \\
\hline \multirow{11}{*}{ Self Expression Effects } & SEE1 & 0.569 & & & & \\
\hline & SEE2 & 0.582 & & & & \\
\hline & SEE3 & 0.599 & & & & \\
\hline & SEE4 & 0.517 & & & & \\
\hline & SEE5 & 0.565 & & & & \\
\hline & SEE6 & 0.505 & & & & \\
\hline & SEE7 & 0.595 & & & & \\
\hline & SEE8 & 0.633 & & & & \\
\hline & SEE9 & 0.573 & & & & \\
\hline & SEE10 & 0.688 & & & & \\
\hline & SEE11 & 0.657 & & & & \\
\hline \multirow{5}{*}{ Self Contacts Effects } & SCE1 & & 0.677 & & & \\
\hline & SCE2 & & 0.657 & & & \\
\hline & SCE3 & & 0.650 & & & \\
\hline & SCE4 & & 0.537 & & & \\
\hline & SCE5 & & 0.751 & & & \\
\hline
\end{tabular}


Table 2. Cont.

\begin{tabular}{|c|c|c|c|c|c|c|}
\hline \multicolumn{7}{|c|}{ Rotated Component Matrix } \\
\hline \multirow{2}{*}{ Dimensions } & \multirow{2}{*}{ Variables } & \multicolumn{5}{|c|}{ Factors } \\
\hline & & 1 & 2 & 3 & 4 & 5 \\
\hline \multirow{15}{*}{ Social Reputation Effects } & SRE1 & & & 0.674 & & \\
\hline & SRE2 & & & 0.731 & & \\
\hline & SRE3 & & & 0.787 & & \\
\hline & SRE4 & & & 0.809 & & \\
\hline & SRE5 & & & 0.795 & & \\
\hline & SRE6 & & & 0.733 & & \\
\hline & SRE7 & & & 0.724 & & \\
\hline & SRE8 & & & 0.662 & & \\
\hline & SRE9 & & & 0.720 & & \\
\hline & SRE10 & & & 0.377 & & \\
\hline & SRE11 & & & 0.760 & & \\
\hline & SRE12 & & & 0.620 & & \\
\hline & SRE13 & & & 0.616 & & \\
\hline & SRE14 & & & 0.764 & & \\
\hline & SRE15 & & & 0.613 & & \\
\hline \multirow{7}{*}{ Occupational Situation Effects and Quality of Life } & OSEQL1 & & & & 0.566 & \\
\hline & OSEQL2 & & & & 0.631 & \\
\hline & OSEQLL3 & & & & 0.647 & \\
\hline & OSEQ̄L4 & & & & 0.577 & \\
\hline & OSEQLL5 & & & & 0.535 & \\
\hline & OSEQL6 & & & & 0.666 & \\
\hline & OSEQL7 & & & & 0.710 & \\
\hline \multirow{7}{*}{ Health Effects } & HE1 & & & & & 0.793 \\
\hline & HE2 & & & & & 0.678 \\
\hline & HE3 & & & & & 0.725 \\
\hline & HE4 & & & & & 0.690 \\
\hline & HE5 & & & & & 0.654 \\
\hline & HE6 & & & & & 0.758 \\
\hline & HE7 & & & & & 0.604 \\
\hline
\end{tabular}

\subsection{Confirmatory Factor Analysis (CFA)}

Confirmatory Factor Analysis, the choice of the best factor model is essential, provided factor loads and errors that have been observed statistically validate it and prove its suitability for the study in question (Brown 2006; Hair et al. 2010; Thompson 2004).

In order to do the CFA, two models were tested-one including all items of the scale and another from which indicators with a factor loading lower than 0.5 were eliminatedboth with and without variable adjustment until the one presenting the most statistically robust results was found. Table 3 presents the results for the two tested models; in the final model, in order to improve the final results, one item was removed. The best model had good statistical results $(\chi 2=7404.786, p=0.001, \mathrm{df}=892, \chi 2 / \mathrm{df}=8.301$, RMSEA $=0.082$, $\mathrm{SRMR}=0.0625, \mathrm{NFI}=0.896, \mathrm{GFI}=0.898, \mathrm{AGFI}=0.882$, and CFI $=0.878)$. Model 2 showed an acceptable adjustment after all variables with a factor loading lower than 0.5 (1 out of 45) had been excluded (Hair et al. 2010).

As far as item and factor reliability is concerned, a good total internal consistency was observed $(\alpha=0.956)$ for the sample composed of 478 accountants working in this area of knowledge. In view of the five-factor structural model that was adopted, the internal consistency of the items was as follows: SEE $(\alpha=0.857)$; SCE ( $\alpha=0.810)$; $\operatorname{SRE}(\alpha=0.928)$; OSEQL $(\alpha=0.842)$; and HE $(\alpha=0.911)$.

In terms of the final measurement model (Model 2), Figure 1 presents the standard path coefficients, showing that they were all significant $(p<0.001)$. 
Table 3. Quality index of the adjustments to some of the tested models.

\begin{tabular}{ccc}
\hline Adjustment Index & $\begin{array}{c}\text { Model 1 } \\
\text { 5 Factors-45 Variables }\end{array}$ & $\begin{array}{c}\text { Model 2 } \\
\text { 5 Factors-44 Variables }\end{array}$ \\
\hline$\chi^{2}$ Satorra Bentler & 7635.583 & 7404.786 \\
df & 935 & 892 \\
$p$-value & $<0.001$ & $p<0.001$ \\
$\chi^{2}$ Satorra Bentler & 8.166 & 8.301 \\
RMSEA & 0.131 & 0.082 \\
SRMR & 0.0671 & 0.0625 \\
NFI & 0.766 & 0.896 \\
GFI & 0.740 & 0.898 \\
AGFI & 0.701 & 0.882 \\
CFI & 0.787 & 0.878 \\
\hline
\end{tabular}

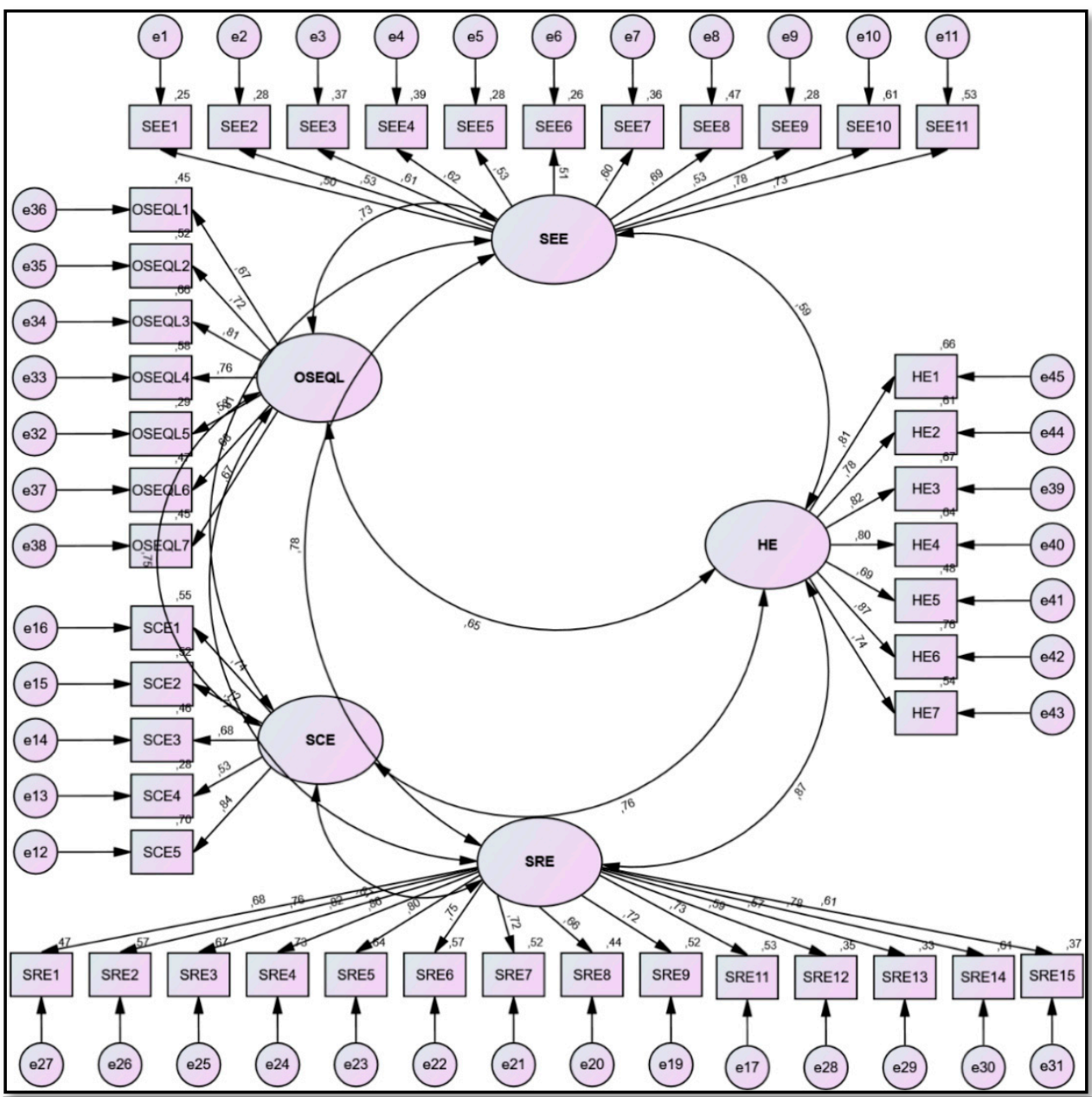

SEE (Self Expression Effects Effects); OSEQL (Occupational Situation Effects Quality of Life); SCE (Self Contacts Effects); SRE (Social Reputation Effects); HE (Health Effects)

Figure 1. ALIPT's final Measurement Model.

\subsection{Final Model Analysis}

The scale used comprises five latent variables representing the scale tested and whose statistical validation results were robust. The factor analysis performed (Table 2) allowed us to verify that all dimensions reached a factor loading above 0.5 , demonstrating the scale's measurement feasibility. To understand the robustness of the model, we calculated the R2 of each latent variable. The R2 is a statistical measure of how close the data are to the fitted regression line. It is also known as the coefficient of determination or the 
coefficient of multiple determination for multiple regression. The higher the value of R2, the greater the explanation of the variability of the data and the more the model fits the sample used (Cameron and Windmeijer 1997).

The latent variables showed different factor loadings highlighting the Health Effects with an $R^{2}$ of 0.71 , the Social Reputation Effects with an $R^{2}$ of 0.692, the Self Contacts Effects with an $R^{2}$ of 0.65 , the Self Expression Effects with an $R^{2}$ of 0.63 , and the Occupational Situation Effects and Quality of Life with an $\mathrm{R}^{2}$ of 0.61 .

Such results demonstrate that this scale fits the sample under study related because the estimated model statistically validated the scale to measure mobbing problems among accounting professionals.

We also found that the covariances between the latent variables were high, an indicator of good scale fit because covariance measures the linear relationship between the variables. The covariance is similar to the correlation between variables, verifying a perfect linear relationship when the correlation coefficient values are close to 1 . The correlation measures both the strength and direction of the linear relationship between two variables (Al-Kandari and Jolliffe 2001). In Figure 1, we can see that the covariance between the latent variables ranged between 0.59 and 0.87 , which demonstrated a good fit for the estimated model/scale.

\section{Discussion}

Mobbing in the workplace is an old and recurrent phenomenon that assumes particular gravity because it becomes a habit in several professions (Zapf and Gross 2001). The consequences of these behaviors are extremely serious for the health of the workers affected, causing problems related to physical and mental health (Health Effects), loss of personal and social confidence (Social Reputation Effects), personal self-exclusion (Self Contacts Effects), increased sadness and unhappiness of the workers affected (Self Expression Effects), and reduced quality of life and work (Occupational Situation Effects and Quality of Life) (de Freitas 2001; Hirigoyen 1999; Torres et al. 2016). In addition to the consequences of mobbing on workers, companies are also affected by this phenomenon that reduces the workers' capacity to work, affecting their performance and efficiency (Bowling and Beehr 2006; Cooper et al. 2004; Figueiredo-Ferraz et al. 2015; Mikkelsen and Einarsen 2001).

The current literature on this issue is quite extensive, with validation carried out in several countries such as Sweden (Leymann 1996), in France (Niedhammer et al. 2006), in Greece (Zachariadou et al. 2018), in Turkey (Korukcu et al. 2014), and also in Portugal (Maximo et al. 2020b). However, concerning the accountancy profession, it is scarce. For this reason, the use of the LIPT45 applied to this professional reality allowed us to conclude that the scale has excellent psychometric properties, showing validity and reliability both in the Exploratory Factorial Analysis and in the Confirmatory Factorial Analysis. The version of the scale, translated into Portuguese, applied to accountants, was validated and allowed future researchers to apply it in studies related to the management area. The dimensions analyzed yielded significant results in line with previous studies where the scale was applied in various socio-professional contexts (Figueiredo-Ferraz et al. 2015; Hauge et al. 2010; Hershcovis et al. 2015; Leymann 1996; Mikkelsen and Einarsen 2001; Thofehrn et al. 2008; Zachariadou et al. 2018).

In the validation of the scale in accountants, something not found in previous validations in other areas of knowledge occurred, mainly in the Portuguese validation (Maximo et al. 2020a). The SRE10 item "Your nationality is ridiculed" was not statistically valid in this scale because it had a factor loading lower than 0.5 (Byrne 2010). We do not exclude the hypothesis that this variable could be tested again to assess whether its weak factor robustness remains in future studies.

Although we have no previous empirical evidence to explain this variable's lack of statistical significance, we believe that it is not adequate when applied to accountancy professionals. In this type of profession, nationality is a reality that does not affect the performance of the work. Accountants follow national and international guidelines in 
executing their work, and there are standard international rules for the execution of tasks (IASB 2021). International rules governing the profession that are common to all accountants maybe have influenced the answers to the nationality question. The assessment of the various factors of mobbing in the workplace allowed us to verify correlations between the dimensions measuring that mobbing in the workplace influences the psychological and social climate of the workers (Hershcovis et al. 2015). The findings of our study are in line with previous research on work-related factors and workplace mobbing (Einarsen et al. 2011; Rayner et al. 2003; Salin 2006; Thofehrn et al. 2008).

Mobbing in the workplace is usually directly related to dissatisfaction with work, superiors, colleagues, and how the organization works, which generates a work climate where the employee's performance is not appreciated (Zachariadou et al. 2018). Mobbing is also associated with work environments where workers' effort is not appreciated, with a tense atmosphere in labor relations caused by the high pressure exerted by excessive workloads (Hershcovis et al. 2015).

The LIPT45 is a scale quickly adapted to the different socio-cultural and labor contexts. Factors such as gender, age, and workplace work do not influence its application and the conclusions drawn from the results obtained. In this sense, its application is universal and can be used as a way to measure mobbing in any area of work and any context where this work is carried out (Korukcu et al. 2014; Maximo et al. 2020b; Niedhammer et al. 2006; Zachariadou et al. 2018).

\section{Final Remarks}

The consequences of mobbing may vary in nature and affect different areas of an individual's life (Figueiredo-Ferraz et al. 2015; Hershcovis et al. 2015; Mikkelsen and Einarsen 2001). This research has contributed to the process of validating the scale for accounting professionals, allowing for a better knowledge of how the mobbing phenomenon prevails in this professional category, despite the difficulty in identifying it. This instrument can also represent a contribution to research in this field. It helps relate the results obtained by the subjects in ALIPT with other variables relevant in understanding the complexity of this phenomenon.

In addition to providing global information-frequency and perceived intensity of the set of behaviors and strategies of mobbing suffered by individuals-ALIPT also allows one to know the behavioral typology of moral, physical, or psychological harassment.

Results obtained from a sample of Portuguese accountants, using a new LIPT scale similar to the original one, made it possible to conclude that, in psychometric terms, this is a statistically reliable measure and one that is valid for studying this subject and this type of labor problem.

In that sense, evidence of validity in this study points to the possibility of ALIPT being used to measure bullying among accountant professionals. The ALIPT internal structure was tested to have the best scale possible to meet the requirements of statistical viability satisfactorily.

The reliability tests that were done produced high Cronbach's Alpha values in every subscale of ALIPT. The results of the Exploratory Factor Analysis were also similar to those referred to in the literature. Subsequently, a Confirmatory Factor analysis was conducted in order to estimate the best model.

Despite the need for more empirical evidence regarding the suitability of this scale, results obtained from the structural models that were tested allow one to say this is a practical, theoretically robust tool to measure this issue, explaining the various types of bullying effects. Both the confirmatory factor analysis and the internal consistency provided psychometric evidence that supports using a five-factor model of this scale.

The previously done analyses made it possible to change the original LIPT scale, adapting it in such a way as to obtain the ALIPT. The validity of ALIPT content was assessed by a panel of experts on psychology, who ensured that the changing of items still kept the basic structure of LIPT. 
A pilot study was also done to assess the readability of LIPT items after they had been adapted to ALIPT to determine whether accountants could understand each item's content and their intelligibility. Regarding the consistency of answers, it was possible to observe there was consonance with the scale, which meant accountants understood perfectly what they were being asked.

Because the factor structure was almost identical to the original version (except for item SRE10), we can conclude that this instrument is good and would probably also be suitable for other occupational groups, such as teachers, health care doctors, call center employees, waiters, managers, enterprise CEOs, and other professional groups in different business and social work contexts.

\section{Limitations of the Study and Proposals for Further Research}

The present study has some limitations, starting with the fact that the sample is small compared to the total population of professionals working as accountants in Portugal. Also, data collection was carried out through a questionnaire survey, and this self-reported collecting data can be considered a limitation. The use of scales may be questioned to the extent that there may be other scales capable of measuring the same reality robustly.

We recommend that the measurement tool created and tested be used in other contexts and professions linked to the accounting area so that ALIPT psychometric properties can be tested again and results from other sample types can be used to compare different realities.

Author Contributions: Conceptualisation, R.S., M.S., A.P.M. and A.D.; methodology, R.S.; software, R.S.; validation, A.P.M. and M.S.; formal analysis, A.P.M. and M.S.; investigation, R.S., M.S., A.P.M. and A.D.; writing-original draft preparation, R.S., M.S., A.P.M. and A.D.; writing-review and editing, R.S., M.S., A.P.M. and A.D.; visualisation, A.P.M.; supervision, M.S.; project administration, R.S., A.P.M., A.D. and R.S.; funding acquisition, R.S. and A.D. All authors have read and agreed to the published version of the manuscript.

Funding: The work of the authors Rui Silva and António Dias is supported by national funds, through the FCT-Portuguese Foundation for Science and Technology under the project UIDB/04011/2020.

Institutional Review Board Statement: Not applicable.

Informed Consent Statement: Not applicable.

Data Availability Statement: Not applicable.

Conflicts of Interest: The authors declare no conflict of interest.

\section{References}

Al-Kandari, Noriah. M., and Ian T. Jolliffe. 2001. Variable selection and interpretation of covariance principal components. Communications in Statistics-Simulation and Computation 30: 339-54. [CrossRef]

Barbera, Jack, and Jessica R. VandenPlas. 2011. All assessment materials are not created equal: The myths about instrument development, validity, and reliability. In Investigating Classroom Myths through Research on Teaching and Learning. Washington: ACS Publications, pp. 177-93.

Cameron, A. Colin, and Frank A.G. Windmeijer. 1997. An R-squared measure of goodness of fit for some common nonlinear regression models. Journal of Econometrics 77: 329-42. [CrossRef]

Bowling, Nathan A., and Terry A. Beehr. 2006. Workplace harassment from the victim's perspective: A theoretical model and meta-analysis. Journal of Applied Psychology 91: 998. [CrossRef] [PubMed]

Brown, Timothy A. 2006. Confirmatory Factor Analysis for Applied Research. New York: Guilford.

Byrne, Barbara. M. 2010. Structural Equation Modeling with AMOS: Basic Concepts, Applications, and Programming (Multivariate Applications Series). New York: Taylor \& Francis Group, vol. 396, p. 7384.

Cooper, Cary L., Helge Hoel, and Brian Faragher. 2004. Bullying is detrimental to health, but all bullying behaviours are not necessarily equally damaging. British Journal of Guidance E Counselling 32: 367-87.

Costello, Anna B., and Jason Osborne. 2005. Best practices in exploratory factor analysis: Four recommendations for getting the most from your analysis. Practical Assessment, Research E Evaluation 10: 1-9.

de Freitas, Maria Ester. 2001. Assédio moral e assédio sexual: Faces do poder perverso nas organizações. Revista de Administração de Empresas 41: 8-19. [CrossRef]

de Matos, Catarina Garcia. 2016. A Responsabilidade Dos Contabilistas Certificados no Exercício da Sua Atividade Profissional. Coimbra: Edições Almedina, S.A. 
Diário da República n. ${ }^{\circ}$ 87/2017. 2017. Available online: https://dre.pt/home/-/dre/106971782/details/maximized (accessed on 12 May 2020).

Duffy, Maureen, and Len Sperry. 2007. Workplace mobbing: Individual and family health consequences. The Family Journal 15: 398-404. [CrossRef]

Einarsen, Stale, Helge Hoel, Dieter Zapf, and Cary L. Cooper. 2011. The concept of bullying and harassment at work: The European tradition. Bullying and Harassment in the Workplace: Developments in Theory, Research, and Practice 2: 3-40.

Figueiredo-Ferraz, Hugo, Pedro R. Gil-Monte, and Victor E. Olivares-Faúndez. 2015. Influence of mobbing (workplace bullying) on depressive symptoms: A longitudinal study among employees working with people with intellectual disabilities. Journal of Intellectual Disability Research 59: 39-47. [CrossRef]

Grau-Alberola, Ester, Hugo Figueiredo-Ferraz, and Pedro R. Gil-Monte. 2019. Violencia Laboral: Discriminacion, Hostigamiento y violencia de genero. In Topicos en violencia: Perspectivas, Reflexiones y Aportaciones. Edited by Angelica Maria Lechuga Quinones, Maria de la Luz Sanchez Soto and Martina Patricia Flores Saucedo. Mexico City: AM Editors.

Hair, Joseph. F., William C. Black, Barry. J. Babin, and Rolph E. Anderson. 2010. Multivariate Data Analysis. London: Pearson Education Limited.

Hasin, Hanafiah Haji, and Normah Haji Omar. 2007. An empirical study on job satisfaction, job-related stress and intention to leave among audit staff in public accounting firms in Melaka. Journal of Financial Reporting and Accounting 5: 21-39. [CrossRef]

Hauge, Lars Johan, Anders Skogstad, and Stale Einarsen. 2010. The relative impact of workplace bullying as a social stressor at work. Scandinavian Journal of Psychology 51: 426-33. [CrossRef]

Hershcovis, M. Sandy, Tara C. Reich, and Karen Niven. 2015. Workplace Bullying: Causes, Consequences, and Intervention Strategies. London: Society for Industrial and Organizational Psychology.

Hirigoyen, Marie France. 1999. El acoso Moral, el Maltrato Psicológico en la Vida Cotidiana (en Español). Barcelona: Ediciones Paidós, Mexico City: Buenos Aires.

IASB. 2021. International Financial Reporting Standards. Available online: https:/ / www.ifrs.org/ (accessed on 12 May 2020).

Korukcu, Öznur, Okan Bulut, Ayla Tuzcu, Zehila Bayram, and Hafize Ozturk Turkmen. 2014. An adaptation of Leymann Inventory of Psychological Terror to health sciences programs in Turkey. Anatolian Journal of Psychiatry/Anadolu Psikiyatri Dergisi 15: 335-43. [CrossRef]

Leymann, Heinz. 1990. Mobbing and psychological terror at workplaces. Violence and Victims 5: 119-26. [CrossRef]

Leymann, Heinz. 1996. The content and development of mobbing at work. European Journal of Work and Organizational Psychology 5: 165-84. [CrossRef]

Luna, Manuel, Carmen Yela, and Alicia Antón. 2003. Acoso Psicológico en el Trabajo (Mobbing). Madrid: Ediciones GPS.

Maximo, Cristiana, Jose Soares Martins, Sergio Dominguez-Lara, Abilio Lourenço, and Margarida Simões. 2020a. Adaptação e Análise da Estrutura Interna da Escala de Mobbing de Leymann (LIPT45 ) Para O Contexto Português. Avaliação Psicológica 242: 56-66. [CrossRef]

Maximo, Cristiana, Jose Soares Martins, Sergio Dominguez-Lara, Abilio Lourenço, and Margarida Simões. 2020b. Adaptation and Analysis of the Internal Structure of the Scale of Mobbing in Leymann (LIPT45) for the Portuguese Context. Avaliação Psicológica 19: 56-66. [CrossRef]

Mikkelsen, Eva G., and Stale Einarsen. 2001. Bullying in Danish work-life: Prevalence and health correlates. European Journal of Work and Organizational Psychology 10: 393-413. [CrossRef]

Monteiro, Ana Paula, Pedro Cunha, Jose Soares Martins, and Margarida Simões. 2021. Mobbing e conflito em contextos de saúde. In Gestão de Conflitos na saúde. Pedro, Cunha, and Ana Paula Monteiro, eds. Lisboa: Pactor, pp. 171-96.

Netemeyer, Richard G., William O. Bearden, and Subhash Sharma. 2003. Scaling Procedures: Issues and Applications. Thousand Oaks: Sage Publications.

Niedhammer, Isabelle, Simon David, and Stephanie Degioanni. 2006. Association between workplace bullying and depressive symptoms in the French working population. Journal of Psychosomatic Research 61: 251-59. [CrossRef] [PubMed]

Ozkan, Azzem, and Mahmut Ozdevecioğlu. 2013. The effects of occupational stress on burnout and life satisfaction: A study in accountants. Quality $\mathcal{E}$ Quantity 47: 2785-98.

Pestana, Maria Helena, and Joao Nunes Gageiro. 2003. Análise de Dados Para Ciências Sociais: A Complementaridade do SPSS. Lisboa: Edições Silabo.

Raykov, Tenko, and George A. Marcoulides. 2006. Estimation of generalizability coefficients via a structural equation modeling approach to scale reliability evaluation. International Journal of Testing 6: 81-95. [CrossRef]

Rayner, Charlotte, Helge Hoel, and Cary Cooper. 2003. Workplace Bullying: What We Know, Who Is to Blame and What Can We Do? Boca Raton: CRC Press.

Salin, Denise. 2006. Organizational Measures Taken against Workplace Bullying: The Case of Finnish Municipalities. Stockholm: Svenska handelshögskolan.

Thofehrn, Maria Buss, Simone Coelho Amestoy, Karen Knopp de Carvalho, Francine Pereira Andrade, and Viviane Marten Milbrath. 2008. Assédio moral no trabalho da enfermagem. Cogitare Enfermagem 13: 597-601. [CrossRef]

Thompson, Bruce. 2004. Exploratory and Confirmatory Factor Analysis: Understanding Concepts and Applications. Washington: American Psychological Association. 
Torres, Analia, Dalia Costa, Helena Sant'Ana, Bernardo Coelho, and Isabel Sousa. 2016. Assédio Sexual e Moral no Local de Trabalho. Lisboa: CITE/CIEG.

Zachariadou, Theodora, Savvas Zannetos, Stella Elia Chira, Sofia Gregoriou, and Andreas Pavlakis. 2018. Prevalence and Forms of Workplace Bullying Among Health-care Professionals in Cyprus: Greek Version of "Leymann Inventory of Psychological Terror" Instrument. Safety and Health at Work 9: 339-46. [CrossRef] [PubMed]

Zapf, Dieter, and Stale Einarsen. 2005. Counterproductive Work Behavior: Investigations of Actors and Targets. Edited by Suzy Fox and Paul E. Spector. Washington: American Psychological Association.

Zapf, Dieter, and Claudia Gross. 2001. Conflict escalation and coping with workplace bullying: A replication and extension. European Journal of Work and Organizational Psychology 10: 497-522. [CrossRef]

Zhou, Xiang, Samma Faiz Rasool, and Dawei Ma. 2020. The relationship between workplace violence and innovative work behavior: The mediating roles of employee wellbeing. Healthcare 8: 332. [CrossRef] [PubMed] 